\title{
Kinga Karpińska
}

Uniwersytet w Białymstoku

e-mail:k.karpinska@uwb.edu.pl

\section{Anna Protasiewicz}

Uniwersytet w Białymstoku

e-mail: a.protasiewicz@uwb.edu.pl

\section{ROLA INNOWACJI POPYTOWYCH I PODAŻOWYCH W ZATRUDNIENIU W PRZEDSIĘBIORSTWACH WOJEWÓDZTWA PODLASKIEGO}

\section{THE ROLE OF DEMAND AND SUPPLY INNOVATIONS IN EMPLOYMENT IN PODLASKIE VOIVODESHIP ENTERPRISES}

DOI: $10.15611 / \mathrm{pn} .2019 .544 .07$

JEL Classification: O30, O31, J21, J23

Streszczenie: Celem artykułu jest analiza wpływu innowacji popytowych i podażowych na zatrudnienie w przedsiębiorstwach w województwie podlaskim. W pierwszej części przedstawiono zagadnienia teoretyczne dotyczące innowacji wyróżnionych ze względu na źródło ich powstawania (proces tworzenia innowacji popytowych i podażowych), a także ich związku ze zmianami na rynku pracy. W części empirycznej zaprezentowano wyniki badań ankietowych przeprowadzonych na 200 przedsiębiorstwach województwa podlaskiego. Ankietowani przedsiębiorcy deklarowali liczbę nowo zatrudnianych pracowników w 2018 roku, a następnie dane te zestawiono z rodzajem wdrażanych przez te podmioty innowacji. Do zbadania związku pomiędzy tymi zmiennymi wykorzystano współczynnik kontyngencji. Ich analiza pozwala stwierdzić, iż w województwie podlaskim większy wpływ na zwiększanie liczby miejsc pracy ma wprowadzanie innowacji popytowych niż podażowych.

Słowa kluczowe: działalność innowacyjna, innowacje popytowe, innowacje podażowe, województwo podlaskie, zatrudnienie.

Summary: The aim of the article is to analyze the impact of demand and supply innovations on employment in enterprises in the Podlaskie Voivodship. The first part presents theoretical issues concerning innovations distinguished due to the source of their creation (the process of creating demand and supply innovation), as well as their relation to changes on the labour market. The empirical part presents the results of a survey carried out on 200 enterprises in the Podlaskie Voivodship. The surveyed entrepreneurs declared the number of newly hired employees in 2018, and then these data were compared with the type of innovations implemented by these entities. A contingency coefficient was used to examine the relationship 
between these variables. Their analysis allows to conclude that in the Podlaskie Voivodship, the introduction of demand-side rather than supply-side innovations has a greater impact on increasing the number of jobs.

Keywords: innovative activity, demand innovations, supply innovations, Podlaskie Voivodeship, employment.

\section{Wstęp}

W literaturze wyodrębnia się wiele podziałów innowacji, wyróżniających je pod względem rozmaitych kryteriów, jednak autorki skupią się na procesie ich powstawania (szerzej o innowacjach [Karpińska, Matel, Protasiewicz 2017]). Poszczególne podejścia do procesów innowacyjnych ewoluowały, skutkując powstaniem kolejnych modeli (model interaktywny czy symultaniczny). Jednak na potrzeby artykułu zaakcentowane zostaną jedynie modele liniowe. Występowanie liniowych powiązań pomiędzy marketingiem, sferą badawczo-rozwojową oraz produkcją zorientowaną na klienta określane jest w literaturze jako popytowy oraz podażowy model powstawania innowacji.

Istotność tematu wynika z obserwacji aktualnych potrzeb przedsiębiorców, zainteresowanych szukaniem rozwiązań innowacyjnych. Przedsiębiorstwa stają się coraz bardziej otwarte i szeroko wykorzystują dostępną wiedzę. Wpływa na to wiele powodów opisywanych w literaturze, jednakże najważniejszą przesłankę stanowią nowe warunki konkurowania. Konkurencja jest coraz silniejsza, a klienci coraz bardziej wymagający. Coraz częściej konsumenci zastanawiają się, w jaki sposób dane przedsiębiorstwo i jego produkty odpowiadają ich osobistym wartościom, zachowaniom i potrzebom. Dlatego też przedsiębiorstwa w coraz większym stopniu starają się angażować klienta w proces innowacyjny.

W związku z tym popytowe podejście do tworzenia innowacji w większym stopniu (niż koncepcja podażowego podejścia do tworzenia innowacji) ogranicza ryzyko przedsiębiorstwa, że wprowadzona innowacja nie odniesie sukcesu na rynku. Jest to niezwykle istotny aspekt $\mathrm{w}$ przypadku małych i średnich przedsiębiorstw (które dominują w województwie podlaskim), z niewielkim kapitałem. Przedsiębiorstwa w województwie podlaskim, które charakteryzują się stosunkowo niższym poziomem innowacyjności niż przedsiębiorstwa z zachodniej części Polski, wykorzystując koncepcję popytową, mogłyby ograniczyć koszty związane z procesem innowacyjnym (jedna z kluczowych barier podejmowania lub kontynuowania działalności innowacyjnej przez te przedsiębiorstwa). Niewątpliwie mogłoby to przyczynić się do zwiększenia konkurencyjności danego przedsiębiorstwa, zwiększenia jego udziału w rynku, a w dalszej kolejności do szybszego rozwoju i tym samym wzrostu zatrudnienia.

Problemem współczesnych przedsiębiorstw jest pytanie, który rodzaj innowacji: popytowe czy podażowe, wpływa w większym stopniu na wzrost zatrudnienia w przedsiębiorstwach w województwie podlaskim? 
W związku z tym przyjęto następującą hipotezę badawczą: zastosowanie popytowego podejścia do tworzenia innowacji w większym stopniu wpływa na wzrost zatrudnienia w przedsiębiorstwach w województwie podlaskim.

Celem artykułu jest określenie wpływu innowacji popytowych i podażowych na zatrudnienie w przedsiębiorstwach w województwie podlaskim.

Wartością dodaną artykułu jest ocena wpływu wdrażanych innowacji popytowych i podażowych na poziom zatrudnienia w przedsiębiorstwach w województwie podlaskim.

\section{Innowacje w ujęciu teoretycznym}

W literaturze nie ma sformułowanej jednolitej definicji pojęcia innowacji, gdyż może być ona określana bardzo wąsko lub szeroko i wieloaspektowo, nie tylko na poziomie przedsiębiorstwa, lecz również w skali gospodarki światowej. Najpopularniejsza definicja, sformułowana przez J. Schumpetera, obejmuje wprowadzenie do produkcji wyrobów nowych lub też udoskonalenie produktów już istniejących, wdrożenie nowego czy udoskonalenie istniejącego procesu produkcyjnego, zastosowanie nowego sposobu sprzedaży bądź zakupów, otwarcie nowego rynku, wykorzystanie nowych surowców albo półfabrykatów oraz wprowadzenie nowej organizacji produkcji [Schumpeter 1960, s. 104]. Współcześnie, definiując pojęcie innowacji, uwzględnia się również innowacje organizacyjne, na przykład wprowadzenie nowej techniki wytwarzania, które całkowicie zmieniają organizację działu produkcyjnego.

Obecnie zdolność do wprowadzania innowacji stanowi jeden z najważniejszych atrybutów przedsiębiorstwa, mający ogromny wpływ na jego pozycję rynkową. Najistotniejsze w tej kwestii wydaje się jednak aplikacja powstałych idei oraz dynamika wprowadzanych zmian w procesie komercjalizacji innowacji [Barańska-Fischer, Blażlak 2016, s. 10]. Dlatego też identyfikacja źródeł powstawania nowatorskich rozwiązań staje się kluczem do analiz dotyczących zarówno poszczególnych podmiotów, jak i całych gospodarek.

Rozpoczęcie procesu innowacji może być rozpatrywane z perspektywy podaży i popytu, a więc źródła powstawania rozwiązań. Niezależnie jednak od przyjętego ujęcia, składa się on z fazy koncepcyjnej i fazy aplikacyjnej. W pierwszej generowane są pomysły oraz rozważane możliwości ich zastosowania, natomiast w drugiej dochodzi do wprowadzenia na rynek opracowanych wcześniej strategii. Faza koncepcyjna poprzedza fazę aplikacyjną, jednak proces innowacji składa się z szeregu interakcji, dlatego też nie zawsze jest on uporządkowany [Janasz, Kozioł-Nadolna 2011, s. 21].

\subsection{Popytowy i podażowy model innowacji}

W latach 50. i 60. XX wieku dominował podażowy model liniowy innowacji, oparty na neoklasycznej teorii wzrostu (technology-push), wywodzący się z koncepcji innowacji J. Schumpetera. Zgodnie z jego założeniami przedsiębiorstwa tworzą nowe 
rozwiązania (produkty), wykorzystując własne zasoby, zwłaszcza technologię. Innowacje nie zawsze odpowiadały na wymagania rynku, dlatego też często nie miały odniesienia do rzeczywistości rynkowej. Innowacje dotyczyły umiejętnego wykorzystania odkryć naukowych oraz spełnienia aspiracji twórczych. Model podażowy składa się z pięciu następujących po sobie faz: badań podstawowych, badań stosowanych i prac rozwojowych, projektowania i prac operacyjnych, produkcji oraz marketingu i sprzedaży [Weresa 2014, s. 32].

W latach 60. i 70. XX wieku wykształcił się z kolei popytowy model tworzenia innowacji. Dotyczy on także liniowego sposobu ich tworzenia, jednak inny jest przebieg powstawania. Pierwszym etapem jest potrzeba rynkowa, a dopiero kolejnymi: prace rozwojowe, produkcja oraz sprzedaż. Nowy etap w procesie tworzenia innowacji, jakim jest identyfikacja potrzeb rynkowych, odzwierciedla konieczność dostosowania się przedsiębiorstwa do oczekiwań nabywców. Różnice podejścia popytowego i podażowego przedstawia tabela 1 .

Tabela 1. Popytowa i podażowa koncepcja innowacji

\begin{tabular}{|l|l|l|}
\hline \multicolumn{1}{|c|}{ Kryterium } & \multicolumn{1}{|c|}{ Popytowa } & Podażowa \\
\hline Nowe rozwiązania techniczne & $\begin{array}{l}\text { głównie tworzone na wyraźne } \\
\text { zapotrzebowanie rynkowe }\end{array}$ & $\begin{array}{l}\text { zwykle generowane } \\
\text { do opatentowania }\end{array}$ \\
\hline $\begin{array}{l}\text { Czas wdrożenia nowego } \\
\text { rozwiązania }\end{array}$ & szybki & powolny \\
\hline $\begin{array}{l}\text { Znaczenie efektów } \\
\text { ekonomicznych }\end{array}$ & podstawowe, rozstrzygające & $\begin{array}{l}\text { do celów ewidencyjnych } \\
\text { i opatentowania }\end{array}$ \\
\hline $\begin{array}{l}\text { Stosowanie rachunku } \\
\text { ekonomicznego }\end{array}$ & pełne & marginalne \\
\hline Postęp techniczny & wynika z potrzeb rynkowych & zrealizowany przypadkowo \\
\hline Bodźce do twórczości technicznej & silne i materialne & spełnienie aspiracji twórczych \\
\hline $\begin{array}{l}\text { Ukierunkowanie działalności } \\
\text { twórczej }\end{array}$ & dostosowanie do popytu & oderwanie od popytu \\
\hline $\begin{array}{l}\text { Udział twórców } \\
\text { we wdrożeniu }\end{array}$ & aktywny & brak \\
\hline Reprezentanci koncepcji & Schmookler & Schumpeter \\
\hline
\end{tabular}

Źródło: [Białoń 2010, s. 29].

Do rozpoczęcia procesu innowacji w ujęciu podażowym konieczne jest zatem prowadzenie działalności badawczo-rozwojowej, dzięki której w kolejnych krokach następuje wdrożenie i sprzedaż nowatorskiego rozwiązania. $Z$ kolei podejście popytowe akcentuje istotę rozpoznania potrzeb rynkowych i odpowiedzi na nie [Żebrowski, Waćkowski 2011, s. 89].

Innowacje popytowe polegają na oferowaniu dóbr i usług, które bezpośrednio odpowiadają potrzebom nabywców. Działalność innowacyjna jest tutaj elastycznym 
reagowaniem na zmieniające się potrzeby rynku - innowacje są podporządkowane potrzebom zgłaszanym przez klientów [Baran, Ostrowska, Pander 2012, s. 27].

Jak wskazuje M. Golińska-Pieszyńska, istotnym czynnikiem podejścia popytowego jest to, że przedsiębiorstwo łączy możliwość technologiczną z potrzebami rynku już w początkowym etapie realizacji procesu innowacyjnego [Golińska-Pieszyńska 2011, s. 63]. Innowacje są zatem nie tylko tworzone wewnątrz danej jednostki, lecz również pozyskiwane z jego otoczenia rynkowego. Źródłem pomysłów i idei są zarówno pracownicy przedsiębiorstwa, jak i przede wszystkim podmioty funkcjonujące w jego otoczeniu - partnerzy handlowi, odbiorcy oraz ostateczni użytkownicy [Z̈elichowska, Furman 2013].

Proces innowacji ukierunkowanej na rezultaty rozpoczyna się od sformułowania strategii innowacji, następnie - przy pomocy informacji pozyskanych od klienta - następuje odkrycie szans rozwojowych. Kolejnymi krokami są: określenie segmentacji rynku, segmentu docelowego oraz pozycjonowanie oferty [Ulwick 2009, s. 24]. Wybór priorytetowego projektu pozwala finalnie na opracowanie przełomowych koncepcji (technologii, produktów), które w największym stopniu będą umożliwiały klientom osiągnięcie najlepszych rezultatów i zaspokojenie potrzeb [Ocieczek, Żelichowska 2014, s. 173]. Z kolei innowacje w ujęciu modelu podażowego tworzone są głównie przez naukę, a następnie wdrażane do gospodarki i weryfikowane przez konsumentów.

Poszczególne podejścia do procesów innowacyjnych ewoluowały, co wynikało ze zróżnicowania czynników i działań tworzących innowacje. Omawiane modele procesu rozwoju innowacji były charakterystyczne dla gospodarek lat 70. i 80 . XX wieku, jednak obecnie są one szeroko stosowane przez wiele rodzinnych, małych i mikro, podmiotów gospodarczych [Blażlak 2016, s. 51]. Współcześnie istotna jest przede wszystkim umiejętność wyrażania skłonności i zdolności organizacji do wdrażania i komercjalizacji nowych rozwiązań - zarówno o charakterze technologicznym (innowacje produktowe i procesowe), jak i nie technologicznym (innowacje organizacyjne i marketingowe) [Ingram, Kraśnicka (red.) 2014, s. 18].

\subsection{Innowacje a zmiany zatrudnienia}

Innowacje odgrywają znaczącą rolę także na rynku pracy - z jednej strony wpływają na popyt na pracę (jego wielkość oraz strukturę), z drugiej zaś warunkują zmiany w podaży pracy.

W literaturze do czynników związanych z wpływem innowacji na zatrudnienie zalicza się [Węgrzyn 2015, s. 147]:

- rodzaj postępu technicznego (kapitałochłonny, kapitałooszczędny, neutralny, korzyści skali);

- obecne i przewidywane preferencje konsumentów;

- $\quad$ rodzaj i strukturę rynku (poziom konkurencji, bariery wejścia i wyjścia);

- charakter i strukturę rynku pracy (elastyczność płac, rola związków zawodowych, preferencje pracowników - praca, czas wolny);

- poziom i jakość kapitału ludzkiego; 
- rodzaj wdrażanych innowacji, który determinuje skalę, dynamikę i kierunek zmian w strukturze zatrudnienia.

Analizę wpływu innowacji na zmiany zatrudnienia można rozpatrywać dwutorowo: jako efekty redukcji oraz kompensacji [Kwiatkowska 2007, s. 27-29]. Efekt redukcji zatrudnienia polega na zastępowaniu pracy żywej kapitałem, prowadzącym do redukcji niektórych miejsc pracy. Zjawisko to dotyczy w szczególności sektorów tradycyjnych i nieefektywnych oraz pracowników o niskich kwalifikacjach. Z kolei efekt kompensacji zatrudnienia polega na powstawaniu nowych miejsc pracy (zwłaszcza w sektorach nowoczesnych technologii), w związku z pojawieniem się nowych produktów lub usług, nowych rynków zbytu.

W dalszej części opracowania zostaną przedstawione wnioski z analizy wpływu poszczególnych rodzajów innowacji na zatrudnienie w województwie podlaskim. Pozwolą one na identyfikację najistotniejszych z nich.

\section{Ocena wpływu innowacji popytowych i podażowych na zatrudnienie}

W świetle przytoczonych powyżej rozważań, twierdzenie, że innowacje sprzyjają powstawaniu miejsc pracy, nie wydaje się oczywiste. Poniżej nastąpi próba poddania go empirycznej weryfikacji. Zebrane dane w bardzo ograniczonym stopniu pozwalają na dokładną analizę wpływu innowacji popytowych i podażowych na wielkość zatrudnienia, niemniej na ich podstawie można zaobserwować ogólne zależności pomiędzy zmiennymi. Badanie ankietowe zostało przeprowadzone wśród 200 przedsiębiorstw z województwa podlaskiego. Badanie odbyło się w okresie wrzesień-październik 2018 roku.

Ankietowani przedsiębiorcy deklarowali liczbę nowo zatrudnianych pracowników w 2018 roku. Dane te zestawiono z rodzajem wdrażanych innowacji przez przedsiębiorstwa. Do zbadania związku pomiędzy tymi zmiennymi wykorzystano współczynnik kontyngencji ${ }^{1}$.

Okazuje się, że zatrudnienie jest skorelowane w większym stopniu z innowacjami o charakterze popytowym. W tabeli 2 zaprezentowano rozkład ilościowy dotyczący innowacji popytowych i zatrudnienia.

Wskaźnik siły związku wyniósł dla tych zmiennych 0,54 (na poziomie istotności² mniejszym niż 0,001). Choć zależności tej nie można nazwać silną, tylko umiarkowaną, to jednak jest istotna statystycznie.

${ }^{1}$ Miara ta określa siłę zależności pomiędzy dwiema zmiennymi analizowanymi za pomocą testu chi-kwadrat. Współczynnik kontyngencji określa miarę związku zmiennych jakościowych, nominalnych, niemierzalnych. Współczynnik ten przyjmuje wartości od 0 (co oznacza niezależność dwóch zmiennych, brak zależności między nimi) do 1 (co oznacza bardzo silną zależność między zmiennymi).

$2 \mathrm{~W}$ pracy przyjęto poziom istotności 0,05 . Gdy wartość statystyki $p$ jest mniejsza niż 0,05 , wtedy wynik jest istotny statystycznie. Oznacza to, że otrzymane różnice są dziełem przypadku z prawdopodobieństwem równym w przybliżeniu 5\%. 
Z kolei w tabeli 3 zaprezentowano rozkład ilościowy dotyczący innowacji podażowych i zatrudnienia.

Tabela 2. Zatrudnienie nowych pracowników a wdrażanie popytowych działań innowacyjnych w 2018 roku

\begin{tabular}{|l|c|c|}
\hline \multirow{2}{*}{ Zatrudnienie } & \multicolumn{2}{|c|}{ Wdrożenie co najmniej jednej innowacji popytowej } \\
\cline { 2 - 3 } & wdrożono & nie wdrożono \\
\hline Wzrost zatrudnienia & 59 & 16 \\
\hline Bez zmian & 27 & 23 \\
\hline Spadek zatrudnienia & 4 & 71 \\
\hline Razem & 90 & 110 \\
\hline
\end{tabular}

$N=200$.

Źródło: opracowanie własne na podstawie danych z przeprowadzonych ankiet.

Tabela 3. Zatrudnienie nowych pracowników a wdrażanie podażowych działań innowacyjnych w 2018 roku

\begin{tabular}{|l|c|c|}
\hline \multirow{2}{*}{ Zatrudnienie } & \multicolumn{2}{|c|}{ Wdrożenie co najmniej jednej innowacji podażowej } \\
\cline { 2 - 3 } & wdrożono & nie wdrożono \\
\hline Wzrost zatrudnienia & 45 & 25 \\
\hline Bez zmian & 35 & 25 \\
\hline Spadek zatrudnienia & 30 & 40 \\
\hline Razem & 110 & 90 \\
\hline
\end{tabular}

$$
N=200 .
$$

Źródło: opracowanie własne na podstawie danych z przeprowadzonych ankiet.

W przypadku innowacji podażowych wartość wskaźnika wynosi 0,16 (na poziomie istotności mniejszym niż 0,001 ), co oznacza, że między wdrażaniem tego rodzaju innowacji a zatrudnieniem występuje bardzo słaba zależność.

Analiza powyższych wyników dostarcza argumentów pozwalających wstępnie pozytywnie zweryfikować hipotezę, że wdrażanie innowacji popytowych ma większy wpływ na zwiększanie liczby miejsc pracy w województwie podlaskim niż w przypadku innowacji podażowych.

Dodatkowo zapytano badanych przedsiębiorców, czy wprowadzane innowacje wiązały się z zatrudnianiem nowych pracowników. W $60 \%$ analizowanych podmiotów uzyskano odpowiedź twierdzącą, co oznacza, że większość przedsiębiorstw w wyniku wdrożenia nowego rozwiązania - na dalszym etapie zatrudniło nowych pracowników. Ponadto większość nowo powstałych miejsc pracy wiązała się z wykonywaniem czynności wymagających posiadania wyspecjalizowanej wiedzy. 
Co więcej, respondenci wskazali również, że to właśnie innowacje popytowe pozwalają na szybszy rozwój przedsiębiorstwa. Głównie dlatego, że podmioty uzyskują szybsze zwiększenie przychodów ze sprzedaży ze względu na: niższe nakłady wdrożeniowe oraz krótszy okres realizacji procesu innowacyjnego, gdyż zwykle tego rodzaju innowacje mają charakter przyrostowy.

\section{Zakończenie}

Innowacje odrywają istotną rolę w zmianach zatrudnienia - zarówno jego wielkości, jak i struktury. Wpływ innowacji na zatrudnienie związany jest z twórczą destrukcją, co oznacza, że z jednej strony innowacja niszczy istniejące miejsca pracy, jednak $z$ drugiej tworzy nowe, bardziej wyspecjalizowane i wymagające często nowej wiedzy stanowiska.

Innowacje popytowe charakteryzuje potrzeba rynkowa, która jest początkiem procesu powstawania, a dopiero kolejnymi: prace rozwojowe, produkcja oraz sprzedaż. Kluczowa jest w tym kontekście identyfikacja potrzeb rynkowych oraz oczekiwań nabywców. Z kolei innowacje podażowe charakteryzuje prowadzenie działalności badawczo-rozwojowej, dzięki której następuje wdrożenie i sprzedaż nowatorskiego rozwiązania. Różnią się tym samym zmiany zachodzące w zatrudnieniu.

Na podstawie wyników przeprowadzonych badań można stwierdzić, że w województwie podlaskim większy wpływ na zwiększanie liczny miejsc pracy ma wprowadzanie innowacji popytowych niż podażowych. Pomiędzy innowacjami popytowymi a zatrudnieniem zaobserwowano istotną statystycznie korelację dodatnią, co oznacza, że wzrost liczby innowacji popytowych skutkuje wzrostem zatrudnienia. Z kolei w przypadku innowacji podażowych nie zaobserwowano takiej korelacji.

Wykorzystanie $\mathrm{w}$ większym stopniu innowacji popytowych pozwala przedsiębiorstwom na: szybszy rozwój przedsiębiorstwa (budowanie przewagi konkurencyjnej), wzrost przychodów ze sprzedaży oraz niższe koszty wprowadzania na rynek produktów i usług innowacyjnych (aspekt ekonomiczny), szybkie zmiany organizacyjno-marketingowe w firmie (nowy model biznesowy) oraz budowanie strategii firmy w oparciu o model innowacji otwartych. Bez wątpienia są to czynniki, które $\mathrm{w}$ dużej mierze przyczyniają się do dynamicznego wzrostu zatrudnienia w badanych przedsiębiorstwach.

Większość badanych przedsiębiorstw w wyniku wdrożenia nowego rozwiązania zatrudniło także nowych pracowników, zwłaszcza osoby o wysokich kwalifikacjach i mających specjalistyczną wiedzę. Widoczny jest w tym przypadku efekt kompensacji zatrudnienia, na który wpływ miało wdrożenie innowacyjnych rozwiązań. 


\section{Literatura}

Baran M., Ostrowska A., Pander W., 2012, Innowacje popytowe, czyli jak tworzy się wspótczesne innowacje, Polska Agencja Rozwoju Przedsiębiorczości, Warszawa.

Barańska-Fischer M., Blażlak R., 2016, Innowacyjność organizacji - istota zagadnienia, uwarunkowania i charakter, [w:] Barańska-Fischer M. (red.), Blażlak R., Szymański G., Innowacje w biznesie. Wybrane zagadnienia, Monografie Politechniki Łódzkiej, Łódź.

Białoń L., 2010, Zręby teorii innowacji. Firma innowacyjna, [w:] Białoń L. (red.), Zarzadzanie działalnościa innowacyjną, Agencja Wydawnicza „Placet”, Warszawa.

Blażlak R., 2016, Modele realizacji procesów biznesowych na rzecz rozwoju innowacji, [w:] Barańska-Fischer M. (red.), Blażlak R., Szymański G., Innowacje w biznesie. Wybrane zagadnienia, Monografie Politechniki Łódzkiej, Łódź.

Golińska-Pieszyńska M., 2011, Polskie praktyki innowacyjne. Aspekty teoretyczne i badania empiryczne, Oficyna Wydawnicza Szkoła Główna Handlowa w Warszawie, Warszawa.

Ingram T., Kraśnicka T. (red.), 2014, Innowacyjność przedsiębiorstw - koncepcje, uwarunkowania i pomiar, Wydawnictwo Uniwersytetu Ekonomicznego w Katowicach, Katowice.

Janasz W., Kozioł-Nadolna K., 2011, Innowacje w organizacji, Polskie Wydawnictwo Ekonomiczne, Warszawa.

Karpińska K., Matel A., Protasiewicz A., 2017, Konsument $w$ działalności innowacyjnej przedsiębiorstw, Polskie Towarzystwo Ekonomiczne Oddział w Białymstoku, Białystok.

Kwiatkowska W., 2007, Zmiany strukturalne na rynku pracy w Polsce, Wydawnictwo Uniwersytetu Łódzkiego, Łódź.

Ocieczek W., Żelichowska M., 2014, Popytowe podejście do innowacji jako nowa koncepcja procesu innowacyjnego w przedsiębiorstwie, [w:] Knosala R. (red.), Innowacje w zarzadzaniu i inżynierii produkcji, Oficyna Wydawnicza Polskiego Towarzystwa Zarządzania Produkcją, Opole.

Schumpeter J., 1960, Teoria wzrostu gospodarczego, Państwowe Wydawnictwo Naukowe, Warszawa.

Ulwick A.W., 2009, Czego chca klienci? Tworzenie przełomowych produktów i usług dzięki innowacji ukierunkowanej na rezultaty, Oficyna a Wolters Kluwer Polska, Kraków.

Weresa M.A., 2014, Polityka innowacyjna, Wydawnictwo Naukowe PWN, Warszawa.

Węgrzyn G., 2015, Innowacje w sektorze a zmiany strukturalne w zatrudnieniu, Wydawnictwo Uniwersytetu Ekonomicznego we Wrocławiu, Wrocław.

Żebrowski M., Waćkowski K., 2011, Strategiczne zarzadzanie innowacjami, Strategie matych i średnich przedsiębiorstw IT, Difin, Warszawa.

Żelichowska M., Furman J., 2013, Koncepcja User-Driven Innovation jako element strategii otwartych innowacji, [w:] Dudzik-Lewicka I., Howaniec H., Waszkielewicz W. (red.), Przedsiębiorczość, innowacje $i$ wiedza $w$ zarządzaniu przedsiębiorstwem, Wydawnictwo Naukowe Akademii Techniczno-Humanistycznej, Bielsko-Biała. 